\title{
ESP Vocabulary Teaching and Learning, Comparing the Language Teacher and Language Learning on the Internet
}

\author{
Msc. Anjeza Brahja \\ Foreign Languages Center. Faculty of Physics and Mathematics Engineering \\ Polytechnic University of Tirana. \\ anjezabr@gmail.com
}

\section{Doi:10.5901/jesr.2013.v3n7p655}

\begin{abstract}
ESP vocabulary teaching and learning has become very important and indispensable in most of the different fields of study for both teachers and learners. This has brought to exploiting various ways of learning and enlarging ESP vocabulary. One of the most popular ways in English learning and teaching is the application of Information Communication Technology or English learning on the Internet. This study tries to investigate the difference or any potential relation between ESP vocabulary teaching by the language teacher and ESP learning on the Internet. Using the Internet to learn a language encourages the use of multimedia and network technology enhancing learning, but on the other hand learning a language face to face with the teacher creates a lot of opportunities to foster participation in different discussion groups developing students' corporation. A questionnaire was done to students who study ESP in their course and will need it in their profession. Participants were selected through random sampling. Students taking part in this questionnaire study at the Faculty of Civil Engineering. Advantages and disadvantages will be discussed for both ways of learning the ESP vocabulary. Comparisons will be done and conclusions will be given concerning the strategies and methods that the ESP teacher and computer programs use in order to ease the recording and learning of ESP vocabulary. Conclusions will include even the fact that students nowadays prefer a combination of the two in order to assimilate the language faster ensuring the fostering of sustainable lifelong learning.
\end{abstract}

Keywords: ESP vocabulary, language teacher, Internet, lifelong learning,

\section{Introduction}

The interest of learning different foreign languages for general and lately for specific purposes has increased a lot and this has been enforced by the usage of the Internet, which makes it possible for easy access to every kind of information in various fields of study.

The Internet is considered as a reliable source of information.

The question if ESP teachers should be different and have a different training than general teachers has always been a controversial one. Nowadays the integration of technology in the teaching of ESP has been the focus of several research projects in various countries around the world. Moreover there are some students who prefer learning ESP on the internet, but a combination of learning ESP with a language teacher and at the same time using the internet is very much applied and preferred. For example Dahlman and Rilling (2001) described a distance learning course in Finland, which was combined with traditional classroom instruction. It was an advanced EFL course for teachers, as part of an 8week summer program at a Finnish university. Students' English was developed by including technology into instruction through various real world language tasks.

Hutchinson and Waters (1987) have answered the questions about the kind of knowledge required by the ESP teachers in that they think that ESP teachers do not need to learn specialist subject knowledge, but they require only three things, which could be considered as the ability to ask intelligent questions. They are:

- Having a positive attitude towards the ESP content;

- Having a knowledge of the fundamental principles of the subject area;

- Having an awareness of how much they probably already know.

Richards (1997) emphasizes that the ESP 'practitioner' needed special skills, underlying that the ESP teacher is a 'special' teacher. The recognition that he/she is someone that stands at the forefront of their profession, came with the establishment of ESP.

Delcloque (1997) says that it would be very useful to consider the nature of teacher training and development and 
use the concept of teacher education, because according to him teacher education is an enabling condition for language education. And if language teaching, is moving from an emphasis on teaching procedures to the fostering of learning, from training to education, then a similar shift in teacher preparation is also required.

But according to Dudley-Evans and St. John (1998), a very important aspect for the teachers to succeed in an ESP teaching process is to identify the learners' needs, which are considered as being the corner stone of ESP and leads to a very focused course.

Richards and Farrel (2005) think that classrooms are not only places where students learn-they are also places where teachers can learn. This means that teachers need to have opportunities for professional development to update their professional knowledge and skills. Richards and Farrel (2005) state that ESP teachers should engage in selfreflection and evaluation, develop specialized knowledge and skills about many aspects of teaching, expand their knowledge base about research, theory, and issues in teaching, develop collaborative relationships with other teachers.

Whereas Harding (2007) points out that ESP teachers don't need to be an expert, but they need to have some understanding of the subject area.

\section{Case studies}

A very well established field in English language teaching is Computer Assisted Language Learning (CALL) or Computer Assisted Language Instruction (CALI).

Two types of CALL for vocabulary learning were analyzed by Fox (1984), one was about uncontextualised exercises seeking one word answers and the other was about putting together or unscrambling a text which formed a context. Fox says that 'these exercises encourage students to consider the computer more as an information source, not so much as a drill master. It offers clues to help them do their tasks and encourage guessing.'

Whereas Higgins (1985) stated that 'mass teaching imposes a single pace on a class' and this could be alleviated by computers.

Kleinmann (1987) demonstrated that the CALL programs were little more than electronic textbooks, after the comparison made to twenty commercially available CALL packages with non CALL materials. He found out that there were no significant differences in reading achievement.

Dunkel (1991) compared groups using computers with a control group using traditional methods. The findings of this comparative research did not have clear advantages for the use of computers. Although Dunkel argued that 'Systematic evaluation of the effectiveness of all aspects of CALL must continue".

According to Frommer and Foelsche (1999) CALL aimed first of all to give students the opportunity to practice grammar and vocabulary so that the class could have more time to do more communicative activities.

Another way of integrating the Internet into the learning and teaching process is using the WebQuests. Dodge (1995) emphasizes 5 steps that a WebQuest must have:

- An introduction that includes background information

- An interesting task

- Some sources of information to finish the task

- Some tips that help to organize the information

- A conclusion

Marco (2002) emphasizes that using WebQuests has many advantages such as: using authentic online materials, developing many skills, promoting learners' motivation etc.

Sullivan and Pratt (1996) made a comparison between two ESL writing environments - a traditional classroom and one where computers were also used. The result was that with the use of the computer and the minimization of the teacher's role, writing did improve a lot.

Nutta (1998) compared students who had computer-based instruction and those with teacher instruction and found out that there was no significant difference between grammar scores on

multiple-choice and cloze tests between them, but it's to be said that the computer-based students had higher scores on open-ended tests.

Another comparison was done by Labrie (2000) who applied 25 French words to do with the body to be learned by a computer and by traditional methods as well. It resulted that for the same learning effect, less time was spent using the computer.

Warshauer (2002) argues that the role of the computer has changed from being a tutor to being a tool.

However Horst et al (2005) note that the effectiveness for language learning of the many vocabulary activities 
available on-line can not be determined, because few of them have been studied in any detail.

\section{Objective of the study}

The purpose of the study was to find out what students think about learning ESP with a language teacher or learning it autonomously on the internet.

The objectives proposed are:

- To know the created atmosphere when learning ESP with a teacher/on the internet.

- To know what they have to do when learning ESP with a teacher/on the internet.

- To know how the ESP teacher/the internet help students assimilate the vocabulary they need.

- To know the skills they master when learning ESP with a teacher/on the internet.

- To know the tasks given after each lesson by the teacher/ internet.

Another purpose was to find out if students prefer a combination of the two to ensure a better learning of ESP as well.

The objectives proposed are:

(For each objective they had to choose one of the four options: the ESP teacher/the internet/ neither of them/ both of them).

- To know who works out the students' language needs in relation to their skills.

- To know who creates situations from their subject area.

- To know who motivates students with variety, authentic materials and fun.

- To know when they have to find additional materials.

- To know how students prefer learning ESP to ensure the fostering of sustainable lifelong learning.

\section{Materials and Method}

Two questionnaires were done to 112 students studying at the Faculty of Civil Engineering, Polytechnic University of Tirana. Some questions of the questionnaires were inspired by Harding (2007), who has given the general approaches the ESP teacher will need to take in order to meet the particular needs of the ESP learner. Whereas some other questions are drawn from personal teaching experience.

All students use the course book entitled Technology 1, Oxford English for Careers (Glendinning, 2007). The course book focuses on different topics related to technology, for example: technological innovations, branches of technology, design, technology in sport, appropriate technology, crime-fighting and security, transport, medical technology, information technology, telecommunication, the future of technology etc.

\section{Participants}

Students studying at the Faculty of Civil Engineering, Polytechnic University of Tirana, study English only the first semester of the first year, that's why 112 first year students took part in the study. They were in the same age range and have had at least 4 years learning English. They are all intermediate or advanced level, but English for Specific Purposes was new to them at the beginning of the course, so the questionnaires were done at the end of the course. During the course they had to find additional information related to different topics of the book and at the end of the course they all had as an obligatory task to prepare a coursework, in which they had to find information from different sources (using the internet as well) about a topic related to their own field of study, looking up new ESP words and expressions and present the coursework orally in front of the class.

\section{Questions of the study}

Questionnaire 1: Learning ESP with a language teacher - graphic 1

Questionnaire 2: Learning ESP on the internet -graphic 2

The questions of the two questionnaires are:

1. How is the created atmosphere when learning ESP with a teacher/on the internet?

\begin{tabular}{l|l|l|l|} 
a) motivating & b) annoying & c) interesting & d) quiet
\end{tabular}


2. What do you have to do when learning ESP with a teacher/on the internet?

\begin{tabular}{c|c|c|c|}
$\begin{array}{c}\text { a) being totally } \\
\text { independent }\end{array}$ & $\begin{array}{c}\text { b) being dependent on the } \\
\text { textbook of the course }\end{array}$ & $\begin{array}{c}\text { c) having to find materials } \\
\text { yourself }\end{array}$ & $\begin{array}{c}\text { d) choosing yourself the } \\
\text { tasks to be done }\end{array}$ \\
\hline
\end{tabular}

3. How does the ESP teacher/the internet help you assimilate the vocabulary you need?

\begin{tabular}{|c|c|c|c|}
\hline $\begin{array}{c}\text { a) understanding the } \\
\text { nature of the students' } \\
\text { subject area }\end{array}$ & $\begin{array}{c}\text { b) giving the meaning of } \\
\text { unknown words }\end{array}$ & $\begin{array}{c}\text { c) making the tasks as } \\
\text { authentic as possible }\end{array}$ & $\begin{array}{c}\text { d)suggesting strategies for } \\
\text { a lifelong remembering of } \\
\text { the ESP vocabulary }\end{array}$ \\
\hline
\end{tabular}

4. Which is the skill/skills you master when learning ESP with a teacher/on the internet?

\begin{tabular}{|l|l|l|l|} 
a)reading/speaking & b)reading/writing/listening & c)reading/writing/speaking & d) all four skills \\
\hline
\end{tabular}

5. After each lesson the teacher/ internet gives tasks to you that are appropriate:

\begin{tabular}{|l|l|l|l|l} 
a) For the lesson taken & b) for the students' level & c) for the students' needs & d) for the students' subject area
\end{tabular}

Questionnaire 3: Learning ESP with a language teacher, on the internet, or a combination of both -graphic 3 The questions of the third questionnaire are:

1. The students' language needs are worked out in relation to their skills by:

\begin{tabular}{|c|l|l|l|}
\hline a) the ESP teacher & b) the internet & c) neither of them & d) both of them \\
\hline
\end{tabular}

2. Situations from your subject area are created by:
a) The ESP teacher
b) the internet
c) neither of them
d) both of them

3. Students are motivated with variety, authentic materials and fun by:

\begin{tabular}{|l|l|l|l|} 
a) The ESP teacher & b) the internet & c) neither of them & d) both of them \\
\hline
\end{tabular}

4. When you learn ESP, you have to find additional materials as well, when you work with:

\begin{tabular}{|l|l|l|l|}
\hline a) The ESP teacher & b) the internet & c) neither of them & d) both of them \\
\hline
\end{tabular}

5. How do you prefer learning ESP to ensure the fostering of sustainable lifelong learning?

\begin{tabular}{|l|l|l|l|} 
a) The ESP teacher & b) the internet & c) neither of them & d) both of them \\
\hline
\end{tabular}




\section{Results and Discussion}

Graph 1. Learning ESP with a language teacher

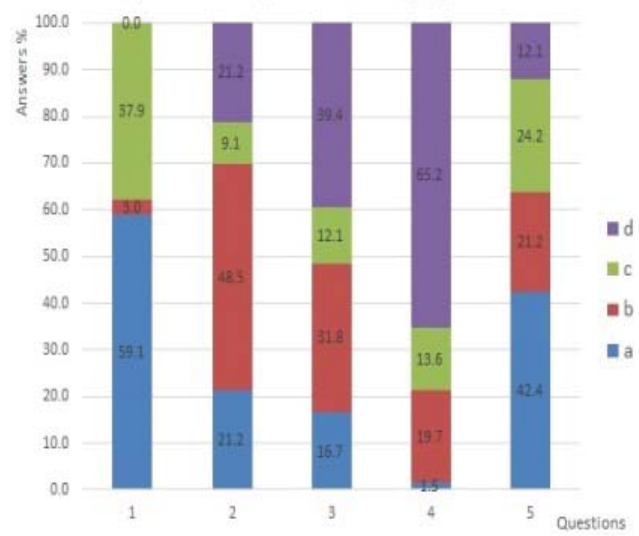

Graph 2. Learning ESP on the internet

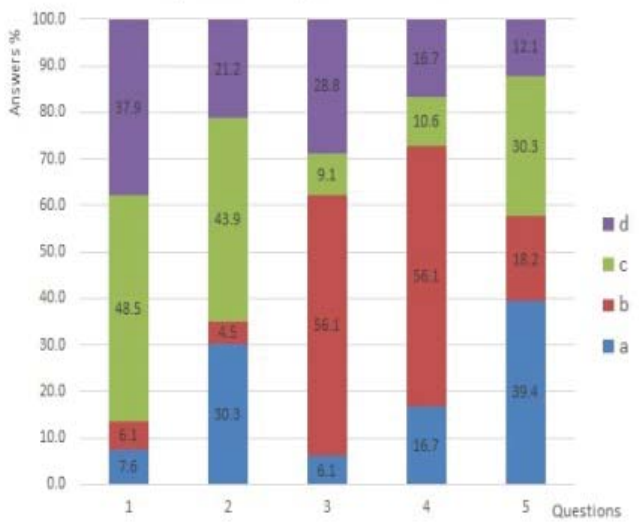

From the graphic results it is seen that $59.1 \%$ of the students consider the created atmosphere when learning ESP with a teacher motivating ( $7.6 \%$ when using the computer). When learning ESP in class you have to learn face to face not only with the teacher, but with the other students as well, so you are appraised and this motivates students to learn more and to give their best. Whereas $48.5 \%$ of them consider it interesting when using the internet and here again we have a good percentage of $37.9 \%$ of students when learning with a teacher. Very few students find it annoying for both cases (3\%teacher/ $6.1 \%$ internet), but it's very interesting to underline the fact that none of the students think it's quiet to learn ESP with a teacher (37.9\% - internet), because when learning ESP in class, students have to collaborate, debate, share knowledge, work in pairs, in groups etc.

Regarding the second question, it is seen that $48.5 \%$ of the students say that they are dependent on the textbook of the course, whereas $43.9 \%$ of them say that they have to find materials themselves when learning ESP on the internet. This shows that when students learn in class, they rely heavily on the textbook they have. So it is the teachers' duty to use additional materials too, found mostly by students, so they become more independent and can come across other sources of information and vocabulary as well. A lot of students feel more independent when learning on the internet, compared to learning with the teacher (30.3\% - internet; $21.2 \%$ - teacher).

The graphic results show that students have chosen with little percentage differences all four options concerning the way the teacher helps them assimilate the vocabulary they need. This happens because the teacher knows the level, the needs and the personality of each group of students and this urges the teacher use different strategies for different group of learners.

Whereas most students $(56.1 \% ; 28.8 \%)$ think that the internet helps them by giving the meaning of certain unknown words and by suggesting strategies for a lifelong remembering of the ESP vocabulary.

From the responses to the fourth question it's clear that the majority of students think that they master all four skills when learning with the teacher (65.2\% - teacher; $16.7 \%$ - internet). This happens because in a learning/ teaching environment in class, students are faced with various activities that enable them combine skills to have a successful learning process. A large number of students (56.1\%) have chosen the three skills (reading, writing, listening) they can master when learning on the internet. Speaking is left out, because students think they can not do the same spoken activities they do when they are in class.

Concerning the tasks given after each lesson, the results show that students have chosen all options with no great differences for the teacher and the internet as well. It's seen that the two options the majority of students have chosen are tasks for the lesson taken (42.4\% - the teacher; $39.4 \%$ - the internet) and tasks appropriate for the students' needs (24.2\%- the teacher; $30.3 \%$ - the internet).

Time is also an important factor within the classroom. Sinclair and Renouf (1988) note, "it is exceptionally difficult to teach an organized syllabus of both grammar and lexis at the same time". 


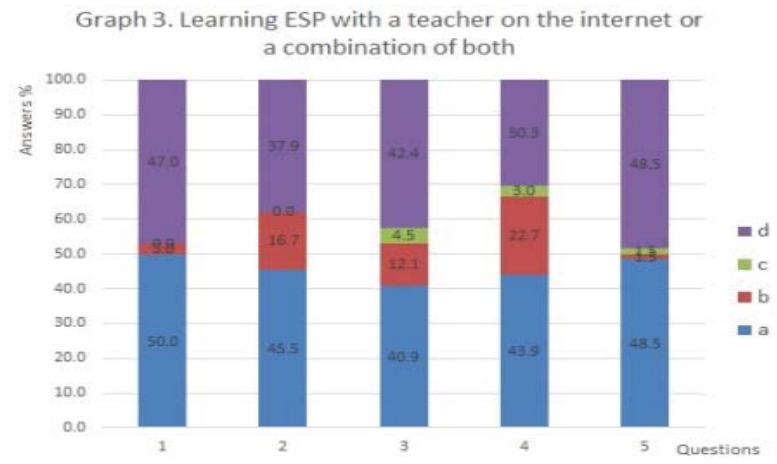

The majority of students think that their language needs are worked out in relation to their skills by the teacher (50\%), whereas $47 \%$ of them think the needs are worked out by both, teacher and internet as well. This happens because students trust more the traditional method of teaching and think the teacher knows them best with their strong and weak points.

Responses to the second question demonstrate that students think that situations are best created by the teacher $45.5 \%$, by the internet $16.7 \%$, and by both $37.9 \%$, (leaving out the third option - neither of them $0 \%$ ). As the results show again most students have chosen the teacher and a combination with the internet as well.

From the responses to the third question, it comes out that the majority of students (42.4\%) think that both teacher and internet motivate students with variety, authentic material and fun. An approximate number has chosen only the teacher (40.9\%). This happens even because of the fact that some students have difficulty in using the internet properly.

Regarding the fourth question about the additional materials they have to find, the majority of students (43.9\%), have chosen the teacher (22.7\% the internet), because when they work in class with the language teacher they have to bring other materials related to the topic of the lesson and at the end of the term they have to hand in and to orally present a coursework in which they will have to write all the bibliography they have used in preparing it. But the graphic shows that $30.3 \%$ have chosen both (teacher and internet). This shows that a lot of students use the internet to learn ESP, while they study it in school with the teacher.

Surprisingly the graphic shows that there is an equal division of percentages concerning the way they prefer learning ESP to ensure the fostering of sustainable lifelong learning. We have $48.5 \%$ the choice for the language teacher and the same $48.5 \%$ the choice for both teacher and internet.

\section{Conclusions}

Students find it more motivating when learning ESP with a teacher than when learning it on the internet. When learning a foreign language, especially when learning it for specific purposes, having a motivating learning environment is crucial to urge students learn and study and as a result having a successful teaching and learning process. Students consider both ways of learning ESP interesting, but underlining that learning ESP on the internet is quiet. This has its advantages and disadvantages as well, because students learn on their own, not having the possibility of sharing knowledge and opinions with others.

Students feel more independent when they learn ESP on the internet, because in this way they surf all the materials they think that can fulfill their needs, but not always all students are competent of using the right materials for specific situations of study. When learning ESP with a teacher, students are very dependent on the textbook of the course, so teachers have to find strategies of making students use other supplementary materials as well, combining teaching in class with learning on the internet. The language teacher is considered as the person who knows students best, so students think the teacher uses methods to help them assimilate all ESP vocabulary and aspects of language they need.

The majority of students think that when learning ESP in class they have the opportunity to master all four skills because of the various activities they do, but when using the internet they leave out speaking as being a skill used differently in both ways of learning.

According to students, the teacher and the internet give a variety of tasks, but answers that dominate are tasks for the lesson taken given by the teacher and this relates somehow to the fact that students are very dependent on the book, 
and tasks appropriate for the students' level concerning the internet.

When it comes to the choice of learning ESP with a teacher, on the internet or both ways, it's noted that students prefer the traditional way of learning, i.e. with a teacher, but not excluding a combination with the internet. Almost half of students asked think that using both ways of learning will help them to better work out their language needs in relation to their skills, that situations in class are best created and that students are motivated with variety, authentic material and fun. So it's understandable that students more and more want to include the internet as well in their learning as a new tool to ensure a more successful learning.

\section{References}

Dahlman, A \& Rilling, S. (2001). Integrating Technologies and Tasks in an EFL Distance Learning Course in Finland. TESOL Journal, 10(1), 4-8.

Delcloque, Ph. (1997). LSP Teacher Training in the use of Technology: Overcoming Technofear. In R. Howard, \& G. Brown (Eds,). Teacher Education for LSP. Multilingual Matters, 100-101.

Dodge, B. (1995). WebQuests: A Technique for Internet-Based Learning. Distance Educator, 1(2), 10 - 13.

Dudley-Evans, T. \& St. John, M.J. (1998) Developments in English for Specific Purposes: A Multidisciplinary Approach, Cambridge University Press.Cambridge, UK: 14, 122- 145.

Dunkel, P. (1991). The effectiveness of research on computer-assisted instruction and computer-assisted language learning. In P. Dunkel (Ed.), Computer-assisted language learning and testing: research issues and practice (pp. 23-24). Newbury House.

Fox, J.D. (1984). Computer-assisted vocabulary learning, ELT Journal, 38(1), 27-33.

Frommer, J. \& Foelsche, O.K.E. (1999). SuperMacLang: development of an authoring system. CALICO Journal, 17(1), 115-141.

Glendinning, E.H. (2007). Technology 1. Students Book. Oxford English for Careers. Oxford University Press.

Harding, K. (2007). English for Specific Purposes. Resource Books for Teachers. Oxford University Press. 3-12

Higgins, J.T. (1985). Grammarland: a non-directive use of the computer in language learning. ELT Journal, 39(3), 167-173.

Horst, M., Cobb, T. \& Nicolae, I. (2005). Expanding academic vocabulary with an interactive on-line database, Language Learning and Technology, 9(2), 90-110.

Hutchinson, T. \& Waters, A. (1987). English for Specific Purposes. A Learning-Centred Approach, Cambridge University Press. 158-163

Kleinmann, H. (1987). The effect of computer assisted instruction of ESL reading achievement. The Modern language Journal, 71(3), 267-276.

Labrie, G. (2000). A French vocabulary tutor for the web. CALICO Journal, 17(3), 475- 499.

Marco, M.J.L. (2002). Internet Content-Based Activities for ESP. English Teaching Forum, 40(3), 20-25.

Nutta, J. (1998). Is computer-based grammar instruction as effective as teacher-directed grammar instruction for teaching L2 structures? CALICO Journal, 16(1), 49-62.

Richards, J.C., \& Farrel, T.S.C. (2005). Professional Development for Language Teachers. Strategies for Teacher Learning. Cambridge University Press. 14-73.

Richards, K. (1997). Teachers for Specific Purposes. In R. Howard, \& G. Brown (Eds.), Teacher Education for LSP, (p. 115). Multilingual Matters.

Sinclair, J. M. \& Renouf, A. (1988). A lexical syllabus for language learning. In R. Carter \& M. McCarthy (Eds.), Vocabulary and Language Teaching, (pp. 140-158). Harlow: Longman

Sullivan, N. \& Pratt, E. (1996). A comparative study of two ESL writing environments: a computer-assisted classroom and a traditional oral classroom. System, 29(4), 491-501.

Warshauer, M. (2002). A developmental perspective on technology in language education. TESOL Quarterly, 36(3), 453-475. 